\title{
A GEOGRAPHIC APPROACH TO MEASURING AND ORGANISING AFFORDABLE MEDICAL AND THERAPEUTIC TOURISM FOR PEOPLE WITH DEMENTIA
}

\author{
Zoya A. Semenova, Anatoliy I. Chistobaev, Valeriya P. Dildina \\ Institute of Earth Sciences, St. Petersburg State University, Russia
}

Manuscript received: October 7, 2020

Revised version: November 19, 2020

\begin{abstract}
Semenova Z.A., Chistobaev A.I., Dildina V.P., 2020. A geographic approach to measuring and organising affordable medical and therapeutic tourism for people with dementia. Quaestiones Geographicae 39(4), Bogucki Wydawnictwo Naukowe, Poznań, pp. 65-71. 3 figs.

ABSTRACT: The article covers the geographical features of the organisation of medical tourism for a group of the world's population suffering from a brain disease - dementia. The main attention is paid to the development of this type of tourism in Russia in comparison with some other countries. The question is raised about the involvement of these people in tourism activities, which could help to improve their health status and improve the living environment of societies. The main problems faced by tourists with the disease dementia are considered. The authors advocate that freedom of movement is the inalienable right of every person. Therefore, the creation of conditions for comfortable travel of people even with mental defects becomes a necessary measure to ensure the sustainable development of accessible tourism infrastructure. The recommendations are given, the implementation of which will allow organising an efficiently working tourist and recreational system that satisfies the needs of these peculiar recreational tourists, as well as the interests of all society representatives.
\end{abstract}

KEYWORDS: population, demography, brain diseases, tourism infrastructure, macroregions of the world, Russia

Corresponding author: Zoya A. Semenova, Saint Petersburg State University, Saint Petersburg, Institute of Earth Sciences, 31/33, 10th line of Vasilievsky island, 199178 Saint Petersburg, Russia; e-mail: semzoy@yandex.ru

\section{Introduction}

To date, more than 7 billion people live on Earth, with the population constantly increasing (PopulationPyramid.net). This fact has many implications for humanity, one of them is the aging population. According to the United Nations' (UN) World Population Prospects (2017), there are over 960 million people in the world aged 60 years and older, which makes up $13 \%$ of the world's population. This category of people is exposed to all sorts of diseases to a greater extent than the younger generation. There are, however, those types of diseases that are caused by an unnatural aging process. These include, for example, a brain disease called dementia. Currently, the number of such patients is about 47 million people and, according to forecasts, their number will increase threefold by 2050 .

In Russia, there is no accurate data on the number of patients with dementia. However, there is information about suffering from dementia and psychosis: their number is determined by 28.9 thousand people (Health care in Russia, 2017: 44). According to statistics from the Ministry of Health, there are no less than 7.5 thousand

\section{sciendo}


dementia patients, and according to the estimates of the leading Russian dementologists, this number is much higher - about 1.7 million people are suffering from this disease ${ }^{1}$. Figure 1 shows the incidence of dementia by age group in the macroregions of the world - four continents. Large differences in indicators are due to a sharp differentiation in the population and demographic characteristics, especially age and health. A particular pattern is observed: the larger the population and the higher the proportion of elderly, the higher is the number of people with dementia ${ }^{2}$.

There are different forms of dementia: vascular, with Alzheimer's disease (the most common) and mixed (Damulin 2002). All these forms are characterised by common signs: degradation of memory, thinking, understanding, and speech; lack of ability to navigate in space; inadequate reasoning and perception of the surrounding reality (Zakharov, Voznesenskaya 2013). In Russia, people with this disease are recognised as incapable, transferred to custody, they are given the 1 st group disability. Most cases of dementia are diagnosed for people over 65, but, as already noted, this disease can affect young people. Even 20-30 years ago, mostly people over 70 years old

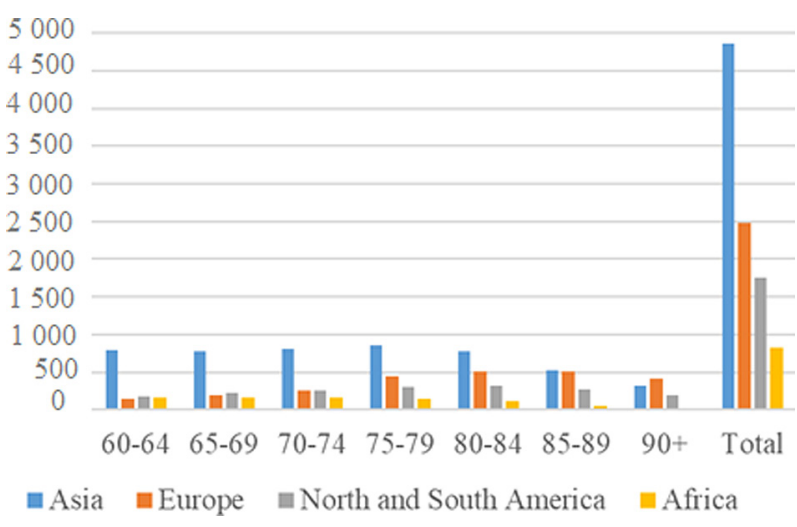

Fig. 1. The annual number of people with dementia by age group and macroregions of the world, in thousands, 2015.

Source: based on World Alzheimer's Report (2015).

How to live suffering from dementia and the person who is close to him (Kak zhit' stradayushchemu dementsiyey i tomu, kto ryadom s nim). Online: https:/ / www.currenttime.tv/a/28729124.html (accessed: 14 March 2019).

2 Incidence in the UK and globally | Dementia Statistics Hub. Online: https://www.dementiastatistics. org/statistics/incidence-in-the-uk-and-globally/ (accessed: 21 March 2019). suffered from dementia, and today it has become almost the norm to diagnose people after 40 with this disease. The main reasons for this trend scientists call an increase in environmental pollution, an increase in the intensity of all components of the lifestyle, and the use of insecticides (Social assistance. Available at: https://memini.ru/social). All of the aforementioned causes are a product of human activity (Sarkar, Webster 2017).

The issues of the rights of protection of persons with disabilities worldwide are seen in the provisions that guarantee the rights of all citizens without compromising their capabilities. Thus, in the Convention on the Rights of Persons with Disabilities (CRPD), the member states undertake to follow principles such as non-discrimination of persons with disabilities, their effective involvement in community service and consideration as full members of society; creating an accessible environment ${ }^{3}$. In Russia, the important guarantees of social protection of persons with disabilities are contained in the Federal Law of November 24, 1995, 181-Ф3 “On Social Protection of Disabled Persons in the Russian Federation". To ensure the preservation of the mental and emotional health of people with disabilities, it is important to give them the opportunity to have an active social life.

\section{Problem statement}

People with dementia can suffer from stigmatisation and all sorts of obstacles that prevent them from feeling like full-fledged members of society (Qiu 2010). In the early stages of the disease, the process of integration of an individual into the social system can help to stop its progression, so patients need to remain among healthy people and be, as far as possible, active members of society. Of course, the peculiarities of the living conditions of dementia patients will be felt, therefore, inevitably, there is a need to provide constant supervision and care by the

\footnotetext{
Basic laws and regulations on the protection of the rights of persons with disabilities. Disability. Recognition procedure, benefits, compensation (Osnovnyye zakony i normativno-pravovyye akty o zashchite prav invalidov. Invalidnost'. Poryadok priznaniya, l'goty, kompensatsii). Online: https://aupam. ru/pages/zakonodatelstvo/shashkova_2013_inva/ page_02.htm (accessed: 14 March 2019).
} 
guardian. It is important to note that in the early stages the patient does not need specialised care: the task of the caregivers and, in general, of the people around them at this time is to delay the exacerbation of the disease as long as possible (Kolanowski et al. 2009).

A change of scenery always has a beneficial effect not only on the sick, but also on the state of any person (Semenova, Chistobaev 2015). Tourism, as a geographical and sociocultural phenomenon, more than any other type of occupation, can help to ensure the physical and spiritual needs of a person, including one who is limited in some parameters of health status. For such a category of people, tourism allows performing the functions of recreation, health, education, and training (Semenova, Chistobaev 2015). Moreover, tourism can help create a geographic worldview for people with dementia. The function of recovery and subsequent health savings is perhaps the most important for patients with moderate and severe dementia. Despite the fact that cases of complete recovery of dementia patients are not yet known, therapy for this disease exists. In mild to moderate dementia, treatment with inhibitors (acetylcholinesterase and memantine) can be effective, especially when they are combined (Qaseem et al. 2008). Treatment of dementia has to be carried out continuously and for life and is impossible without the use of psychological and cognitive training, which are aimed at restoring and compensating for impaired cognitive processes in a patient. The implementation of this function can be achieved through medical and therapeutic tourism.

In Russia, as in many other countries of the world, there are medical facilities for the care of patients with dementia: these are boarding schools, outpatient psycho-neurological centres (institutions that treat patients with dementia on an outpatient basis or in a day hospital), boarding houses (pensions) and sanatoriums, where treatment methods are constantly being improved. An equally important therapy that helps stop the development of the disease is art therapy - a complex of exercises that improves the emotional state and helps fight depression. Such activities have a positive effect on cognitive functions, because the brain zone, in which memories are stored, also acts as a centre connecting familiar music and the emotions associated with it. For example, a group singing popular songs excites people with dementia stirring memories that help them feel better. Among non-drug methods, organised excursions, visits to museums, sports entertainment are particularly beneficial (Baker, Corrigan-Charlesworth 2017) ${ }^{4}$.

In recent years, special tourist destinations have emerged in a number of countries with the aim to help people with dementia organise and conduct their trip with comfort (World Alzheimer's Report, 2015). The main difficulties that people with dementia often face are: problems with mobility (coming to an unfamiliar place), disorientation caused by background noise, fancy decor and shiny surfaces; fear of being lost when gaps in memory occur, distortions in visual perception or spatial awareness; impaired ability to interact with the environment, for example, when paying for goods and services, counting money, remembering PIN codes, etc. All this means that it is necessary to create a special tourism infrastructure that would allow creating a favourable environment for travelling both the patients themselves and their accompanying ones.

\section{Global practice in creating enabling infrastructure for dementia patients}

A striking example of the existing and developed accessible infrastructure is the Dutch village of Hogewey, which is both a nursing home and a settlement where people with dementia can take advantage of useful activities: go to the store and hairdresser, attend the theatre, restaurant. There are 240 specially trained staff per 150 patients of the centre. In addition to entertainment and leisure, occupational therapy is also practiced: patients are encouraged in their help in cooking, cleaning and even caring for each other. The centre is run mainly at the expense of the state. Grants amount to USD 22 million, and another USD 3 million geriatric centre helps out

\footnotetext{
Baker C., Corrigan-Charlesworth J., 2017. Visiting the Memory Café and other dementia care activities: Evidence-based interventions for care homes. Jessica Kingsley Publishers, London. Online: http://search.ebscohost.com/login.aspx?direct $=$ true $\& \mathrm{db}=$ nlebk $\& A N=15$ $26665 \&$ lang $=$ ru\&site $=$ eds-live\&scope $=$ site (accessed: 17 November 2020).
} 
for leasing facilities for conferences and other events; the restaurants and cafes are open to any person, even a non-resident of the village ${ }^{5}$.

There are more and more institutions around the world every year where dementive patients can spend their leisure time. For example, in the United States, there are over 300 so-called Memory Cafés. In such institutions, patients and their caregivers come to talk with each other, to play board games. In Norway, as part of the implementation of the plan to improve the quality of life of people with dementia in Oslo, the Alma House project was created, which consists of several premises that imitate the apartments of elderly people with dementia ${ }^{6}$. Its equipment clearly demonstrates how new technologies that make life easier for patients can and should be used. For example, devices have been created that remind you of the time when you need to take medicine; a TV remote is adapted to the needs of a specific viewer; the mattress is equipped with a special sensor, an external security button is installed, etc. In the capital of Japan, Tokyo, in 2017, the 'Restaurant of False Orders' was opened, in which elderly people with dementia work. The feature of service in this restaurant is that instead of your order, you can get something completely unexpected. Restaurant visitors are already aware of the possibility of such an incident, so complaints are not accepted. Such institutions are created with the aim of attracting public attention to the problem and to raise public awareness that there are people who have a different perception of the world, that it is necessary to learn to interact with them. The Russian equivalent of institutions for patients with dementia are the Moscow private boarding house Malakhovka. However, while in the Netherlands the village of Hogewey is financed by the state, the Malakhovka patients

Hogeway: A village for people with dementia in Holland (Khogvey: derevnya dlya lyudey s dementsiyey v Gollandii) - Старость в радость (Old age is a joy). Online: https://starikam.org/poleznaya-informaciya / zarubezhnyj-opyt/ xogvej-derevnya-dlya-lyudej-s-demenciej-v-gollandii/ (accessed: 08 April 2019).

6 How to deal with dementia in Europe? Norway experience (Kak boryutsya s dementsiyey v Yevrope? Opyt Norvegii) - Riga.lv. Online: https://www.riga. $\mathrm{lv} / \mathrm{ru} /$ news/kak-boryutsja-s-demenciei-v-evropeopyt-norvegii?15249 (accessed: 08 April 2019). pay for living themselves or their relatives $\mathrm{do}^{7}$. Moreover, in the nursing homes of some countries, free schools operate on an ongoing basis for those who care for people with dementia. The socalled 'schools of care' are one-day seminars in which geriatric psychiatry specialists talk about all aspects of patient care, ranging from paperwork for disability (in the early stages of the disease) to the organisation of hospice care for the sick (in the last stages of the disease) ${ }^{8}$.

An accessible environment for people with dementia is a large set of activities that have yet to be created and implemented. Nowadays, scientists all over the world began to think about the development of special standards that allow patients to feel comfortable. In addition to the aforementioned facilities, a special design of buildings and space should be noted. This includes colour (colour should be bright and contrast, so as not to merge with furniture), rooms should be on the first floor with an intuitive layout ${ }^{9}$. In Russia, there is already an example of a developing project for creating and adapting a space for people with disabilities in different groups - this is the Tiflocenter 'Vertical'10. Its authors have developed some criteria, the compliance with which allows destinations to call themselves 'dementia-friendly'. The availability of special pointers allowing free navigation in space; adaptation of accommodation facilities, food, toilet rooms to the needs of people with dementia; specially trained personnel to work with a specific contingent; cooperation with organisations involved in the treatment of this disease; promoting and raising public awareness of dementia.

Geriatric Center "Malakhovka» (Geriatricheskiy tsentr «Malakhovka). Online: Available at: https://spravochnik-pansionatov.ru/geriatricheskij-centr-malaxovka/ (accessed: 16 March 2019).

8 Winter "School of Care" for relatives caring for elderly people with Alzheimer's disease (Zimnyaya «Shkola Zaboty» rodstvennikov, ukhazhivayushchikh za pozhilymi lyud'mi s bolezn'yu Al'tsgeymera). Online: https://memini.ru/discussions/30823 (accessed: 09 April 2019).

9 Space for people with dementia (Prostranstva dlya lyudey s dementsiyey). Online: http://www.berlogos.ru/article/prostranstva-dlya-lyudej-s-demenciej/ (accessed: 16 March 2019).

10 "Accessible environment" - Production and integrated supply of equipment («Dostupnaya sreda» - Proizvodstvo i kompleksnaya postavka oborudovaniya). Online: https:/ / tiflocentre.ru/ (accessed: 08 April 2019). 


\section{Country ranking by the level of development of affordable tourism for people suffering from dementia}

The 'Third Age Travel' organisation according to the data for 2018 has compiled a ranking of countries for traveling by people of the third age (Fig. 2). This ranking includes 100 countries, which are ranked based on the following criteria: price-quality ratio; ease of visiting (visa formalities); the number of interesting places and objects to visit; state of the environment; crime level; level of medical care; level of corruption; awareness of age-related issues (in terms of the proportion of the population over 60$)^{11}$. Based on these eight indices, an idea of the strengths and weaknesses of each country is created. Japan ranks first in this ranking, taking the top position on two factors: awareness of age-related issues and low crime rates. For two other factors - health care and ease of visiting - this country is in the top ten. Once Japan had a reputation as an expensive destination, but at present it is on the same level with Europe and North America. Most of other countries included in the Top 20 are

11 Home - Third Age Travel. Online: https://thirdagetravel.com/ (accessed: 16 March 2019). in Western Europe. Among them - the 'big five': Great Britain, Germany, France, Italy and Spain. The Top 20 also includes other Western European countries, as well as the USA and Canada in North America, New Zealand and Australia. Four countries - Norway, Ireland, Hong Kong and Iceland - could enter the Top 20 if they were not so expensive for tourists. The remaining countries, ranked in the group from the 21st to the 40th, are located mainly in Southern and Eastern Europe. As for Russia, it is far from the most favourable destination for elderly people to visit. Tourism for the elderly is represented here mainly in the form of accommodation in boarding houses.

The combination of the above factors for traveling determines the content of the definition of 'accessible tourism'. Therefore, accessible tourism is a complex of tourist services, which is specially adapted for people either with limited mobility, or with limitations of the senses, or with intellectual or mental limitations. Since this definition includes the category of the population that suffers from dementia, it is quite applicable to people with this disease.

In modern Russia, there is no single state body that is focused on resolving the issues of organising travel for dementia patients and that could coordinate subordinate organisations or delegate an appropriate authority to local authorities.

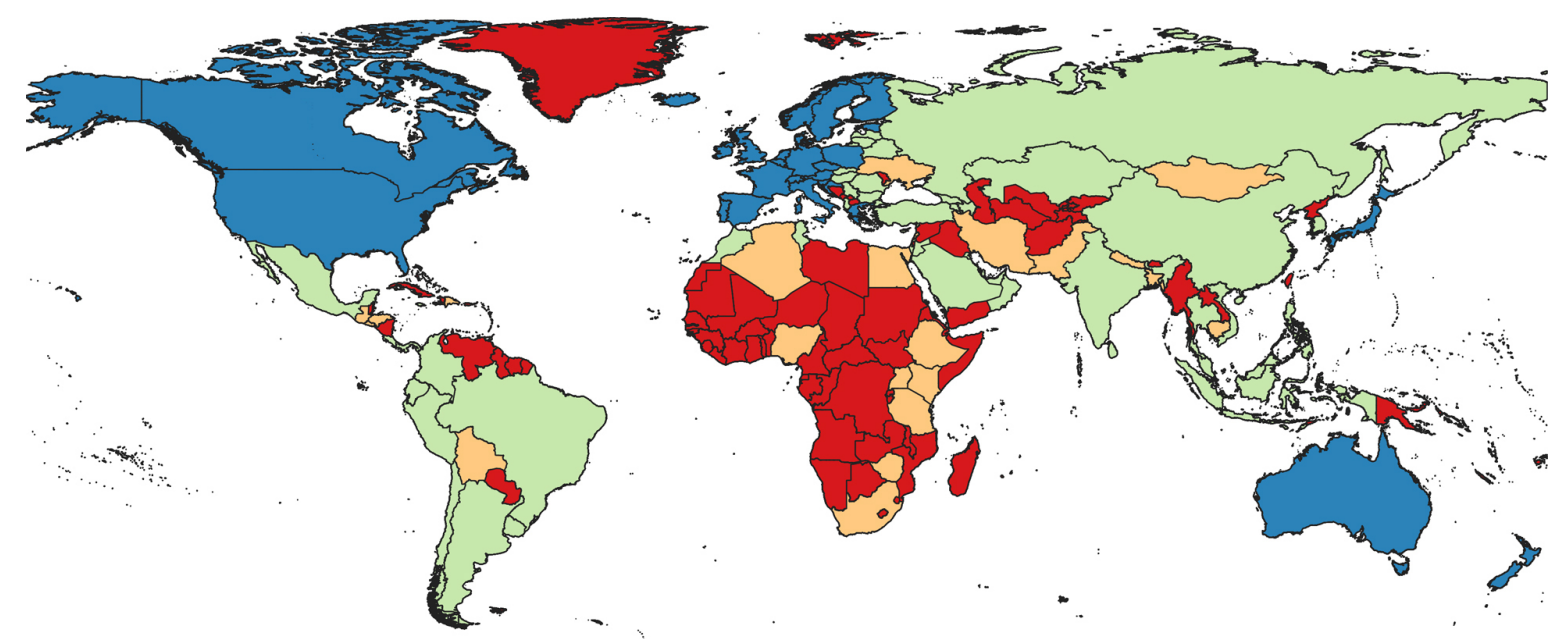

Third Age Travel Country Rating

No data

Lowest-rated countries

Medium-rated countries

Highest-rated countries

Fig. 2. The position of the world countries according to the rankings for travel of people of the third age. Source: based on: Home - Third Age Travel. 


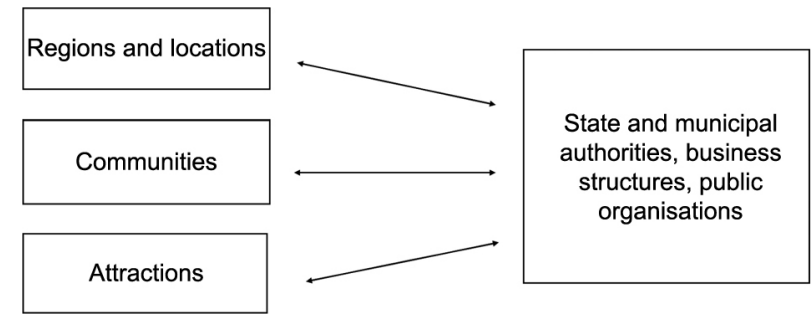

Fig. 3. The system of interaction of entities in the regulation of tourism for people with dementia. Source: composed by authors.

Corresponding business entities are also underdeveloped. To ensure the sustainable development of this activity, it is necessary to create a coherent system that includes interrelated elements. Such a system is presented in Figure 3.

The establishment and subsequent operation of the presented system of interrelated structural elements will help the progressive development of accessible tourism, the interaction of regions and countries. Note that the element of regions and localities includes both government organisations and business enterprises interested in developing this tourist destination. The Communities, in turn, are groups of people with dementia, as well as organisations (World Health Organization - WHO, United Nations - UN, World Tourism Organization - UNWTO) acting in their interests. Tourist attractions include a collection of entertainment and activities. Determining the strength of interaction between subjects in regulating tourism for people with dementia is an independent topic that the authors intend to cover in the next article from the perspective of an integral approach to measuring this strength, and not only for this type of tourism, but also for others - psychological, dental, and yoga tourism.

Ensuring the interaction of the above-mentioned elements of the structures can serve as a basis for the establishment of close ties between them, as well as for the emergence of new autonomous units within the single state body managing tourism for people with dementia. Its absence is currently holding back the development of this important service area. Attempts to develop projects and targeted programs at regional and local levels are not sufficient to solve problems. The intersection of duties within regions and at interregional levels causes the underdevelopment of partnerships between administrative entities of the Russian Federation and municipalities.
Creating a public system of tourism development for people with dementia will allow uniting the efforts of stakeholders, developing and implementing a unified policy in the field of social adaptation and integration into the social system of dementia patients, provide funding for social projects within government bodies, and improve the situation of socially unprotected groups of the population.

In 2016, the UNWTO held a seminar entitled 'Accessible Tourism as an Effective Business Strategy', in which Taleb Rifai (the organisation's general secretary from 2010 to 2017) called on companies to assist in the development and implementation of projects to increase the accessibility of tourism, focusing on the fact that tourism is the guaranteed right of every person. This seminar is far from being the first event of this kind: as early as 2011, an agreement was signed between the Russian Federation and the EU countries, according to which people with disabilities are exempted from visa fees ${ }^{12}$. In 2012, Moscow hosted the 2nd International Conference dedicated to the development of affordable tourism, which identified practical steps for creating an equal opportunity society in our country. An important event of this conference was the discussion of the 'Memorandum on topical issues of the development of accessible tourism in Russia', containing a list of activities necessary for the development of tourism in the Russian Federation for people with disabilities. One of them is the creation of the Russian Association of Accessible Tourism (RAAT) ${ }^{13}$.

\section{Conclusion}

With the increasing anthropogenic pressure on the human environment, the ever-increasing rates of urbanisation, population aging and a number of other factors, there are more and more

12 European countries cancel service fees for people with disabilities (Yevropeyskiye strany otmenyayut servisnyye sbory dlya invalidov). Online: http:// www.atorus.ru/press-centre/new/11478.html (accessed: 04 March 2019).

13 The Association of Accessible Tourism will appear in Russia (V Rossii poyavitsya Assotsiatsiya dostupnogo turizma). Online: https://www.itmexpo.ru/media/news/1323 (accessed: 04 March 2019). 
people with dementia every year. According to the authors, the specially created tourism is capable of suspending this process to some extent. With a growing segment of patients with dementia, this type of activity in the service market can be viewed by entrepreneurs as promising, since in the modern world there is a tendency to increase the number of stakeholders in resolving this issue. In a number of countries around the world, numerous funds that work with elderly people have appeared, new types of infrastructure have emerged that meet the requirements of different segments of the population. For dementia patients, state subsidies are allocated for the development and implementation of projects to create centres and even villages, where they live and receive the necessary treatment.

The global scientific and cultural community should strive to ensure that dementia is considered as a special way of life, involving demented patients in socially useful activities. Of course, when people with dementia come to a late stage, they will need specialised care, but before the onset of this period, they need understanding, protection and an adapted environment for safe leisure. Creating tourism infrastructure accessible to this category of people is an important area of scientific research (including the field of medical geography) and practical activities of government and business.

The authors of this article intend to continue research in the field of medical tourism as one of the directions of modern medical geography, which received a theoretical and methodological substantiation in our previous publications (Semenova, Chistobaev 2015, 2013, 2010, 2011; Chistobaev, Semenova 2011, 2013). Thus, we confirm the earlier stated proposition of the process of evolution of medical geography as an interdisciplinary science on the formation and conservation of public health in the environment (Semenova, Chistobaev 2015). One of the components of the structure of this science is medical tourism (Chistobaev at al. 2018; Semenova, Chistobaev 2017), in particular, its sub-categories - medical and therapeutic tourism.

\section{Acknowledgment}

The study is financed by RFBR project № 19-05-00104 «Spatio-temporal features and regularities of medical tourism development at the global and regional levels of health system organization».

\section{References}

Chistobaev A.I., Semenova Z.A., 2011. World medical-geographical schools of thought: Leaders and achievements. Geography in School 4: 21-25.

Chistobaev A.I., Semenova Z.A., 2013. Evolution of scientific ideas of quality of life of the population. Terra Humana 3(28): 247-251.

Chistobaev A.I., Semenova Z.A., 2010. From Gippokrata to E.N. Pavlovskogo: Founders of medical geography. Geography in School 9: 37-41.

Chistobaev A.I., Semenova Z.A., 2011. The scientific disciplines interfaced to medical geography: Subordination and interaction. Geography in School 6: 14-20.

Chistobaev A.I., Semenova Z.A., 2018. Spatio-temporal dynamics of the global medical tourism. Journal of Environmental Management and Tourism 9(2): 267-275.

Damulin I.V., 2002. Bolezn' Al'tsgeymera i sosudistaya dementsiya (Alzheimer's disease and vascular dementia). Moscow: 86.

Health care in Russia (Zdravookhraneniye v Rossii), 2017. Rosstat (Federal State Statistic Service) Moscow: 170.

Kolanowski A., Fick D.M., Buettner L., 2009. Recreational activities to reduce behavioural symptoms in dementia. Geriatr Aging 12(1): 37-42.

Qaseem A., Snow V., Cross Jr. J.T., Forciea M.A., Hopkins Jr R., Shekelle P., Santaguida P., 2008. Current pharmacologic treatment of dementia: A clinical practice guideline from the American College of Physicians and the American Academy of Family Physicians. Annals of Internal Medicine 148: 370-378.

Qiu W.Q., Dean M., Liu T., George L., Gann M., Cohen J., Bruce M.L., 2010. Physical and mental health of homebound older adults: An overlooked population. Journal of the American Geriatrics Society 58: 2423-2428.

Sarkar C., Webster C., 2017. Urban environments and human health: Current trends and future directions. Current Opinion in Environmental Sustainability 25: 33-44.

Semenova Z.A., Chistobaev A.I., 2017. Meditsinskiy turizm novaya otrasl' ekonomiki.Gosudarstvo i biznes (Medical tourism is a new branch of economy. State and business). Modern problems of economics: Proceedings of the IX International Scientific and Practical Conference. SPb: 160-164.

Semenova Z.A., Chistobaev A.I., 2013. Impact of living conditions on population health. Geography in School 6: 33-38.

Semenova Z.A., Chistobaev A.I., 2015. Medical geography and population health: The evolution of knowledge. Monograph. Publishing house "Yevropeyskiy Dom", St. Petersburg: 252.

World Alzheimer's Report, 2015. The global impact of dementia: An analysis of prevalence, incidence, cost and trends. Alzheimer's Disease International (ADI), London.

World Population Prospects, 2017. United Nations: Aging. Online: https://www.un.org/en/sections/issues-depth/ageing/index.html (accessed: 26 February 2019).

Zakharov V.V., Voznesenskaya T.G., 2013. Nerono-psikhicheskiye narusheniya. Diagnosticheskiye testy (Neuropsychiatric disorders: Diagnostic tests). MEDpress-inform, Moscow: 320. 